\title{
INTEGRATED ASSESSMENT OF THE RUSSIAN ECONOMY COMPETITIVENESS
}

\author{
Svetlana Kotenkova ${ }^{1}$ \\ Julia Varlamova ${ }^{2}$, \\ Natalia Larionova ${ }^{3}$ \\ Irina Rudaleva ${ }^{4}$
}

\begin{abstract}
In the context of the modern economic processes development at the regional level, such an aspect as regional competitiveness plays an extremely important role. To quantify the competitiveness of the regions of the Russian Federation, 10 subjects were taken. A comparative analysis was

strong differentiation, due to the geoeconomic features already mentioned above. One can use the successful experience of countries such as Canada, China and Ireland in the formation of directions considered in this paper for increasing the competitiveness of regions.
\end{abstract} carried out on the basis of 35 indicators divided into 7 blocks depending on factor affiliation. The result of the analysis is the ranking of the considered regions of the Russian Federation in terms of competitiveness.The quantitative analysis carried out in conjunction with a qualitative assessment based on the SWOT analysis allows us to create a relatively clear picture of the competitiveness ratio of individual Russian regions, the main characteristic of which is their rather

Keywords: competitiveness, regions of Russia, BRICS

\section{Introduction}

The regions of the state are inalienable elements of the market economic system; in this regard, it is the competitive advantages of the regions that determine the formation of favourable conditions for the efficient operation of most business entities. Thus, through pursuing a policy of

\footnotetext{
${ }^{1}$ Kazan Federal University. e-mail Julia.Varlamova@kpfu.ru. Tel. 89063249373.

${ }^{2}$ Kazan Federal University. e-mail Julia.Varlamova@ kpfu.ru. Tel. 89063249373.

${ }^{3}$ Kazan Federal University. e-mail Julia.Varlamova@ kpfu.ru. Tel. 89063249373.

${ }^{4}$ Kazan Federal University. e-mail Julia.Varlamova@ kpfu.ru. Tel. 89063249373.
} 
increasing regional competitiveness, such important state functions as sustainable social and economic development of the country and improving the well-being of citizens are realized. [3, P. 575]. In the work of Singatullina G. et al., the impact of the investment climate on the competitiveness and infrastructure performance in the context of a region [7, P. 546] are analysed. Mishra A.K. et al. consider the transport and institutional infrastructure of European countries [4, P. 131], Montalbano P. et al. focus on investment and technological infrastructure using the method of model building [5, P. 790]; Charles V. et al. focus on the energy infrastructure $[2, \mathrm{P}$. 261]. In a study by Zhang K.H. et al. the component analysis method is used to build a composite index of infrastructure development, which indicates the validity of further use of this method [10, P. 531].

\section{Methods}

The aim of the study is to identify factors that influence competitiveness. The data for 7 years for the regions of the Russian economy are taken as a sample. To assess the
91

competitiveness of the regions of the Russian Federation, ten subjects were taken. The selection of these entities was based on the competitiveness rating of the regions of the Russian Federation. This rating was chosen as the initial one due to the fact that it provides the opportunity to use the results of assessing the competitiveness of Russian regions in the framework of international comparisons with the Global Competitiveness Index of the World Economic Forum. The main research methods are the index method, and SWOT-analysis of the regional competitiveness factors.

The use of only quantitative indicators in assessing the competitiveness of regions narrows to a certain extent the reliability of information about the situation in a particular region. Based on this, the analysis also used qualitative indicators (for example, availability of strategies, programs for socio-economic development, etc.).

As mentioned above, the integral level of competitiveness of a region is a relative indicator, and therefore should not depend on the size of the territory or the population of the 
region. Therefore, all the particular signs of competitiveness are included in the calculation of integral (summary) values with units of measure expressed in relative quantities - per capita, volumetric, share.

In the final part of the analysis, the regions were ranked by comparative characteristics of the obtained integral indices, taking into account the weight coefficients of each block of indicators. A competitiveness analysis for the regions of the Russian Federation under consideration will be carried out in two stages: analysis of the integral indices in each block and analysis of the final integral index.

The initial element of a qualitative competitiveness assessment within the framework of this work is the analysis of strategic documents of the territories for the content and essence of the general goal, priority directions, as well as the format for developing these documents as regards the participation of public representatives in this process.

The methodology for the SWOT analysis of regional competitiveness factors was chosen as the basis for the next stage of the qualitative competitiveness assessment
92

for the individual Russian Federation regions, when an analysis of the strengths, opportunities, and threats within the framework of this assessment format makes it possible to formulate recommendations for the constituent entities of the Russian Federation regarding management and increasing their competitiveness. Evaluation of each of the parameters separately was made in a comparative section of all 10 subjects, which allows us to compare the strengths and weaknesses of the territories, as well as their capabilities and threats, to highlight the general and different aspects of their competitiveness.

The work involved 35 different quantitative indicators, divided into five groups: legal acts, general indicators, indicators of infrastructure development, innovative potential, indicators of foreign economic relations of the region, indicators of business development and basic investment indicators.

When calculating the integral indices for each indicator, the method of relative differences was chosen. It involves obtaining estimates of particular indicators using 
standardization according to the

formulas:

$$
\begin{aligned}
t_{i j} & =\frac{x_{i j}-x_{j \min }}{x_{j \max }-x_{j \min } *} \\
t_{i j} & =\frac{x_{j \max }-x_{i j}}{x_{j \max }-x_{j \min }}
\end{aligned}
$$

* For situations when the larger values of the indicator reflect the best positions of the region

** For situations when the lower values of the indicator reflect the best positions in the region.

$$
T_{i}=\frac{\sum_{j=1}^{n} t_{i j}}{n}
$$

The coefficient values will belong to the region $[0 ; 1] .=1$ can be achieved only if the $\mathrm{i}$-th region has the best values for all particular indicators.

The weights of each block were determined using the hierarchy analysis method. In turn, the total integral index for all indicators as a whole (based on arithmetic mean values for each block) is
When calculating the integral index for each block of indicators, the arithmetic mean method was selected from partial coefficients, which is based on the formula: calculated by the arithmetic mean method weighted by the weighted indices of each of the indicator blocks.

\section{Results And Discussion}

As a result of the calculations made, the results for the integral index were obtained (Fig. 1). 


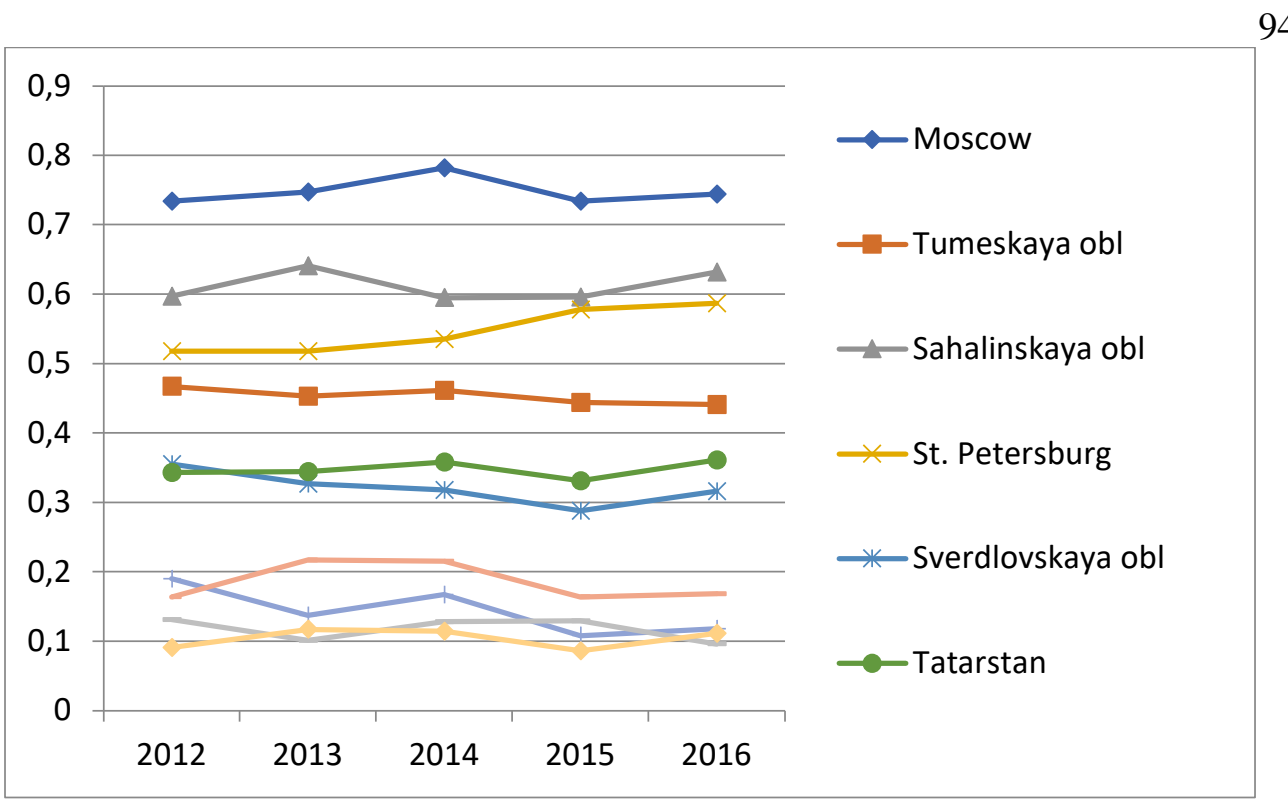

Fig 1. Integral index

As we can observe, the only region with a relatively high level of competitiveness is the city of Moscow, with a final index of more than 0.7 throughout the entire period. Thus, the range of values for the capital of Russia varies from 0.734 to 0.782 , reflecting a large gap from other regions. This phenomenon is due to the high level of socio-economic development of the city, high investment and innovative potential, as well as the most powerful potential for business development. Moscow's closest competitor is the Sakhalin Oblast which integral index is higher than that of the third-ranking city St. Petersburg almost throughout the entire period. Moreover, throughout the entire period under review, the integral index for St. Petersburg varies from
0.518 to 0.587 , showing steady growth (if compared with Moscow as of 2014, the St. Petersburg index is slightly more than a quarter lower than the same in the Russian capital).

The fourth position is taken by the Tyumen region, followed by the Republic of Tatarstan. The Sverdlovsk region is behind them; it could well stand on a par with the Republic of Tatarstan, if not for the negative trend in the dynamics of the integral index, in particular, the dynamics in 2012-2013.

At the same time, the Republic of Tyva, the Karachay-Cherkess Republic, the Republic of Ingushetia and the Chechen Republic, in turn, are uncompetitive regions; this naturally proceeds from the fact that all four regions occupy the places with the 
lowest competitiveness rating on the basis of which the objects of research were selected.

Thus, the regions were ranked according to the level of competitiveness

Table 1 - Total Integrated Indices for 2008-2016

\begin{tabular}{|c|c|c|c|}
\hline & $\begin{array}{l}\text { The } \\
\text { increase in } \\
\text { integral } \\
\text { indices in the } \\
\text { period under } \\
\text { review }(\%)\end{array}$ & $\begin{array}{c}\text { The average } \\
\text { value of integral indices }\end{array}$ & $\begin{array}{l}\text { Place } \\
\text { in the ranking } \\
\text { of these } \\
\text { subjects } \\
(2016)\end{array}$ \\
\hline Moscow & 5.2 & 0.734 & 1 \\
\hline $\begin{array}{l}\text { Tumenskaya } \\
\text { obl. (region) }\end{array}$ & -1.6 & 0.448 & 4 \\
\hline $\begin{array}{l}\text { Sahalinskaya } \\
\text { obl. (region) }\end{array}$ & 25.1 & 0.593 & 2 \\
\hline St. Petersburg & 21.0 & 0.532 & 3 \\
\hline $\begin{array}{l}\text { Sverdlovskaya } \\
\text { obl. (region) }\end{array}$ & -4.0 & 0.320 & 6 \\
\hline $\begin{array}{l}\text { Republic of } \\
\text { Tatarstan }\end{array}$ & 15.0 & 0.336 & 5 \\
\hline $\begin{array}{ll} & \text { Republic of } \\
\text { Tyva } & \end{array}$ & -20.8 & 0.146 & 8 \\
\hline $\begin{array}{r}\text { Karachay- } \\
\text { Cherkess Republic }\end{array}$ & 2,4 & 0.167 & 7 \\
\hline $\begin{array}{l}\text { Republic of } \\
\text { Ingushetia }\end{array}$ & 47.7 & 0,098 & 10 \\
\hline $\begin{array}{l}\text { Chechen } \\
\text { Republic }\end{array}$ & 101.8 & 0,092 & 9 \\
\hline
\end{tabular}


However, it is important to emphasize here that this classification is primarily relative, and therefore such a critical situation in the regions under consideration in terms of their competitiveness is largely determined by the large margin between the "reference region" (on the basis of its maximum performance calculation of integral indices), which status in most of the analysed indicators was held by Moscow, and other subjects of the Russian Federation. Despite the relativity of the competitiveness assessment, the socio-economic situation in the Republic of Tyva, the Karachay-Cherkess Republic, the Republic of Ingushetia and the Chechen Republic definitely reflects their extremely low level of competitiveness in absolute terms.

The next stage of the study was a SWOT analysis for regional competitiveness factors in a format for comparing all ten entities in terms of their strengths and weaknesses, as well as opportunities and threats.

The strengths of the regions were divided into three categories geographical and geopolitical location, economic potential and additional advantages - each of which reflects qualitatively different competitive advantages.

The geographic and geopolitical location, as well as the resource potential of a region represent the initial positions of the territories, that is, the conditions under which the entities operate and the initial resources that they possess. These are the most "tough" competitive factors. Strengths of this category are present in all of the subjects presented; however, the quality of this advantage is heterogeneous for each of them. Cities of federal significance are expected to have the greatest geopolitical influence in comparison with other regions: the implementation of a number of international and state functions sets them apart from other entities that do not have such a large administrative resource at their disposal. This definitely affects, albeit to a greater extent indirectly, on the competitiveness of both capitals, compensating for the absence of large mineral deposits or any other natural resources. In turn, the rich in their mineral deposits Tyumen, Sakhalin and 
Sverdlovsk regions, as well as the Republic of Tatarstan determine their own development areas, by and large, based on the mining and manufacturing industries, especially the first two regions. While the Sverdlovsk region and the Republic of Tatarstan are characterized by a more diversified economy, and the question of geographical location in terms of involvement in the transport network is more relevant for them. The regions of the North-Caucasian Federal District are distinguished by the presence of favourable climatic conditions that determine a fairly developed subsistence economy and the agro-industrial complex; however, it is not entirely correct to compare these entities with the Tyumen region: such a volume of fossil resources is not found in any other subjects of the country, besides the southern regions.

From the point of view of economic potential, the main leader is the city of Moscow. The Russian capital has almost everything necessary to be the best region of the country, and even more: a high innovative potential is provided by a highly developed business environment and an overconcentration of a large number of medium and large enterprises; the huge investment flow reflects the leading role of the capital in the process of entry and exit of foreign and domestic investment flows; large volumes of labour resources are able to provide the regional economy for a long time, especially due to the constant influx of more and more qualified personnel. In turn, the Sverdlovsk region is characterized as one of the leading industrial centres of Russia. The Tyumen and Sakhalin regions are characterized by a high growth rate of investment flows into the regions, mainly in the raw materials industry.

On the contrary, the republics of the North Caucasus Federal District and the Republic of Tyva do not have such significant economic potential that would allow them to provide any kind of self-sufficiency both financially and in production, which determines their main problem - subsidisation of their economy.

However, along with the strengths, the following shortcomings in the development of the regions under consideration can be noted, which determine their lack of competitiveness of one nature or another. 
A number of regions are distinguished by a common sensitivity to fluctuations in market conditions, in prices for hydrocarbon raw materials (Tyumen region) and other main articles of Russian exports and imports, including changes in financial markets (the city of Moscow). Also widespread is the problem of low transport infrastructure equipment status (Republic of Tyva, Sakhalin region), as a result of the inaccessibility of a larger area of these territories, or an excessive load on the roadway (the cities of Moscow and St. Petersburg) as a consequence of the high population density and concentration of the main infrastructure facilities both in the city itself and in their agglomerations as a whole.

The problem of labour resources availability is also quite relevant, and for all regions in general; the difference is only in the degree of need for them. The exception is the city of Moscow, accumulating the best cadres of the country. Moreover, in neighbouring St. Petersburg, the question of the need for qualified personnel is quite acute.
98

Problems of low innovation and investment development are characteristic of the republics of the North-Caucasian Federal District, as well as the Republic of Tyva. Also, these regions are characterized by relatively low incomes of the population (as a result, low consumer demand in the domestic regional market), the absence of large industrial enterprises, the instability of the financial system (these regions are subsidised), a high share of the "shadow" sector of the economy, and the aforementioned problems of low level of transport and infrastructure equipment status and an acute shortage of personnel.

The possibilities of each of the regions differ to a greater extent. If for the republics of the North Caucasus Federal District, they, by and large, consist in the realisation and maximum use of the tourist and recreational potential that the regions possess, as well as the development of the production of building materials, then for the city of Moscow, potential is qualitatively different. If anyone from the Russian regions is capable of becoming a global financial centre, then this is definitely the Russian capital. However, the 
availability of a number of structural problems in the economy also determines such areas for increasing competitiveness as the rational spatial distribution of economic infrastructure, the development of post-industrial clusters and the weakening of administrative barriers. Relatively similar opportunities are presented in St. Petersburg, where in addition there is the question of improving the transport infrastructure of the city. The analysis of the "threat" parameter allows us to look at the regions under consideration through the prism of a pessimistic forecast of the external environment development.

One of the main threats to resource regions, mainly represented by the Tyumen and Sakhalin regions, is fluctuations in energy prices, which is determined by the high level of dependence on investment flows and international exports. The Republic of Ingushetia, Tyva, the Chechen and Karachay-Cherkess Republics are also characterized by threats from the increase in their lagging behind other subjects of Russia in terms of basic socio-economic indicators, which can be facilitated by such trends as the migration of economically active people, a decrease in the competitiveness of regional enterprises, and a decrease in budgetary volumes. transfers and, accordingly, the risk of budgetary tension.

\section{Summary}

The analysis allows us to compile a relatively clear picture concerning the correlation of the competitiveness of individual Russian regions; the main characteristic of their comparison is their fairly strong differentiation, due to the already mentioned national characteristics.

\section{Conclusions}

The analysis shows that, despite the variety of resources in qualitative and quantitative terms, the presence or absence of a certain type of infrastructure and many other factors, the most competitive are regions with a diversified economic structure that can attract effective domestic and foreign investment resources.

Among the possible directions of increasing the competitiveness of the region are the following: increasing the innovative potential of the region; an 
active policy of regional authorities aimed at accelerating the growth of the high-tech sector of the economy; intensification of innovative activities using public-private partnership mechanisms, including forms of venture financing. An important tool for such a policy can be the creation of new and expansion of the existing educational clusters.

\section{Acknowledgements}

The work is performed according to the Russian Government Program of Competitive Growth of Kazan Federal University.

\section{References}

BRICS: Joint Statistical Publication, 2015, 235 p.

Charles V., Zegarra L. F. Cultural heritage, tourism and regional competitiveness: The Motor Valley cluster // Culture and Society. Volume 3. Issue 4. December 2012. P. 261-273

Hongyi Li, Xiangdong Wei, Danyang Xie. Competitiveness of the Hong Kong economy // China Economic Review.
Volume 20. Issue 3. September 2009. P. 573-586

Mishra A.K., Rao, G. Vishwanath, B. An assessment of competitiveness in emerging Asian economies with special reference to India // International Journal of Economic Policy in Emerging Economies. 9(2). 2016. P. 127-144

Montalbano P., Nenci, S. The trade competitiveness of southern emerging economies: A multidimensional approach through cluster analysis // World Economy. 37(6). 2014. P. 783810

OECD library database //

http://www.oecd-ilibrary.org/statistics

Singatullina G., Altman K. Analysis of Investment Climate in Russia by the Example of Foreign Direct Investment. 4th International Multidisciplinary Scientific Conference on Social Sciences \& Arts SGEM 2017. Conference Proceedings Book 1, Volume 1. 2017. P. 545-556

The world bank database // www.data.worldbank.org 
Periódico do Núcleo de Estudos e Pesquisas sobre Gênero e Direito

Centro de Ciências Jurídicas - Universidade Federal da Paraíba V. 8 - N 06 - Ano 2019 - Special Edition ISSN | 2179-7137 | http://periodicos.ufpb.br/ojs2/index.php/ged/index

World Investment Report 2017: Annex

Tables // UNCTAD, www.unctad.org

Zhang K.H. How does foreign direct

investment affect industrial

competitiveness? Evidence from China

// China economic review. 30. 2014. P.

$530-539$ 